\title{
Competing Interests in the Underwater Cultural Heritage: A Question of Balance
}

\author{
M. Z. Mohd Nor* \& A. Zahid**
}

The exploitation of the underwater cultural heritage (UCH) involves various competing interests, which are of private and public, commercial and non-commercial nature. The 2001 UNESCO Convention on the Protection of the Underwater Cultural Heritage (CPUCH) aims to deal with various issues apropos those competing interests. Its basic concerns include how UCH should be best protected, how in situ preservation should be practised, whether $\mathrm{UCH}$ should be commercialized at all or not, and whether salvage should be included in the UCH law. This paper examines these said competing interests and then looks for a balance between them. With an in-depth analysis of the concerned principles and rules, it argues for combination of 'mutuality interests' in consonance with the basic legislative scheme of the $\mathrm{CPUCH}$. This approach is meant for the exploitation of $\mathrm{UCH}$ both for commercial and noncommercial purposes, which would, in fact, fulfill the expectation of the international community.

\section{Keywords}

Underwater Cultural Heritage, Competing Interests, Exploitation, CPUCH, In Situ Preservation

* Associate Professor of law at Universiti Kebangsaan Malaysia (National University of Malaysia). LL.B (IIUM), LL.M. (Malaya), Ph.D. (Edinburgh). ORCID: http://orcid.org/0000-0001-7824-7984. The author may be contacted at: zuhdi@ ukm.edu.my / Address: Faculty of Law, UKM, Bangi 43600, Selangor, Malaysia.

** Senior Lecturer of law at Universiti Kebangsaan Malaysia (National University of Malaysia). LL.B./LL.M.(U. Dhaka), LL.M.(Dalhousie), Ph.D. (Manchester). ORCID: http://orcid.org/0000-0003-3877-7280 The author may be contacted at: anowar_zahid@ukm.my / Address: Faculty of Law, UKM, Bangi 43600, Selangor, Malaysia. DOI: http://dx.doi.org/10.14330/jeail.2016.9.1.06 


\title{
1. Introduction
}

The United Nations Educational, Scientific and Cultural Organization ("UNESCO") Convention on the Protection of the Underwater Cultural Heritage of 2001 ("2001 CPUCH") defines underwater cultural heritage ("UCH") as "all traces of human existence having a cultural, historical or archaeological character which have been partially or totally under water, periodically or continuously, for at least 100 years." UCHs are often commercially transacted for their high prices. The $2001 \mathrm{CUPCH}$ thus expresses the concern for commercialization and competing interests surrounding $\mathrm{UCH}$ as follows:

\begin{abstract}
The importance of the underwater cultural heritage, the responsibility of all States in its protection, the public interest in it, the need for non-intrusive access to it, the need to prevent activities directly or incidentally affecting it, the concern for commercialization, the need for cooperation between different subjects to protect it, the will to codify and progressively develop international law in this field, the priority of in situ conservation of the underwater heritage. ${ }^{2}$
\end{abstract}

The value of UCH concerns groups of communities, whether public or private, who have vested interest in its discovery, preservation or exploitation of such heritage. ${ }^{3}$ These groups include States either asserting jurisdiction over the UCH, or with verifiable interests and link (flag state or states of historical and cultural origins), identifiable owners, underwater marine archaeologists, commercial salvors, leisure divers, artefact and art collectors, auctioneers as well as the international community as a whole. ${ }^{4}$ The United Nations Convention on the Law of the Sea ("UNCLOS") provides the basic guideline for disposing UCH granting "preferential rights to the State or country of origin, or the State of cultural origin, or the State of historical and archaeological origin." ${ }^{5}$ Meanwhile, the 2001 CPUCH calls for "cooperation among States, international organizations, scientific institutions, professional organizations,

$12001 \mathrm{CUPCH}$ art. 1(1)(a).

2 UNESCO Convention on the Protection of the Underwater Cultural Heritage 2001, ("2001 CPUCH"), pmbl, available at http:/www.unesco.org/new/en/culture/themes/underwater-cultural-heritage/2001-convention/official-text (last visited on May 8, 2016).

3 S. Dromgoole, Underwater Cultural Heritage and International Law 96-133 (2013).

4 The 2001 CPUCH recognizes the mankind in general as the beneficiary of the heritage. See J. Roach, Sunken Warship and Aircraft, 20 Marine PoL'y 352 (1996).

$5 \quad$ UNCLOS art. 149. 
archaeologists, divers, other interested parties and the public at large..."6 However, there are still many ambiguous cases in the course of preserving or disposing those UCHs.

The purposes of this research are to examine the competing interests of the discovery groups of historic wrecks and to look for a balance there under international law. This paper is divided into four parts including a short Introduction and Conclusion. Part two will provide an overview of treasure hunting and competing interests. Part three will tackle issues related to $\mathrm{UCH}$ including the public right to enjoy $\mathrm{UCH}$, in situ preservation, prohibition of commercial exploitation, and application of salvage law. The Malaysian cases will be also tackled here.

\section{Competing Interests in the Discovery and Exploitation of UCH}

$\mathrm{UCH}$ is potentially rich with historical and cultural value in terms of material objects as well as evidentiary importance of intangible knowledge of the past civilizations. As its discovery may form a lucrative business, it may be a source of conflict, as well.

In Carman's view, preservation of UCH (wrecks lying on the seabed) "in an unchanged state and without public access makes them potentially available for scientific study." Often described as 'time capsules,' shipwrecks yield vast amount of data of old ships and their cargoes that could not be known otherwise. ${ }^{8}$ A study on trade items discovered on a number of historic wrecks in Southeast Asian waters proves that a scientific analysis of discovered UCH could even put some established historical facts into question. ${ }^{9}$ According to Brown, historic wrecks and cargoes found in the Straits of Malacca (Malaysia) could be indicators of trade items available at that time, as merchants would not only have selected products appropriate to the route and its commercial criteria, but also offer undisputable proof of certain technological advancements in maritime trade of that period. ${ }^{10}$ Therefore, $\mathrm{UCH}$

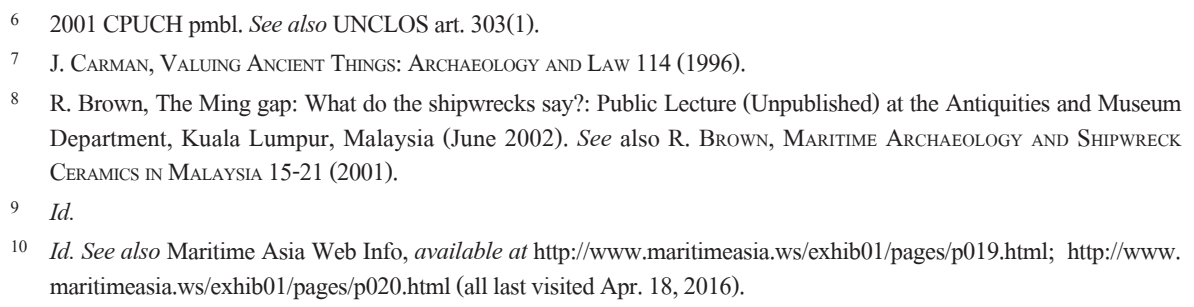


objects which are recovered and later traded and float in the open market "free of their documented context" could aptly be described as "irreparable loss to science and history.",11

Furthermore, in the course of recovery of $\mathrm{UCH}$, their associated environment is often damaged and permanently destroyed due to improper and destructive recovery methods of the treasure hunting salvage companies. ${ }^{12}$ The treasure hunters often work under the pressure and constraint of time and cost, creating a tendency to resort to quicker but highly destructive methods. By doing that, they forsake the less commercially attractive objects and destroy the collective value of the UCH associated environment. The worst scenario is that they neither care for, nor are trained in archaeological values and principles. Clemency Coggins describes the damage caused by looters and treasure hunters as follows: ${ }^{13}$

Once a site has been worked over by looters in order to remove a few saleable objects, the fragile fabric of its history is largely destroyed. Changes in soil colour, the traces of ancient floors and fires, the imprint of vanished textiles and foodstuffs, the relation between one object and another, and the position of a skeleton - all of these sources of fugitive information are ignored and obliterated by archaeological looters. ${ }^{14}$

Paolo Monteiro, a marine archaeologist from the Angra Do Heroismo Museum in Terceira argued that archaeology and treasure hunting do not mix for the following reasons:

Treasure hunting is driven by commercial logic; time is money, so they have to work quickly to raise as many artefacts as possible and sell them. An archaeologist can spend 10 years or more studying and excavating a ship, conserving its objects and publishing findings. We gain an enormous amount of information and knowledge from this work. With treasure hunters, all of this is lost; records are not kept and artefacts are spread all around the world in private collections. ${ }^{15}$

11 L. Prott, Opening Note: Cultural Heritage Looted From Iraq, in Resolution of Cultural Heritage Dispute 1 (2003).

12 C. Beltrame \& D. Gaddi, Report on the First Research Campaign on the Napoleonic Brick, Mercure, Wrecked off Lignano, Udine, Italy in 1812, 31 Int'L J. Nautical Archaeology 60-73 (2002). Dr. Beltrame while speaking on the North Italian Adriatic observed that "The plots of the side-scan sonar show clear traces of the furrows left on the sea floor both by 'rapidi' and by 'turbosoffianti.' Both types of fishing implements have a devastating impact upon submarine archaeological deposits, causing damage and dislodging."

13 However, this does not say that treasure hunters are necessarily looters.

14 C. Coggins, Archaeology and the Art Market, 175 ScI. 263 (1972).

15 S. Williams, A Treasure Trove to Protect, 87 UNESCO Sources 7 (1997), available at http://www.abc.se/ m10354/ publ/heritage.htm (last visited Apr. 18, 2016). 
Reports of the recovery of artefacts from the HMS Sussex, the Titanic, as well as the relatively recent legal dispute between Spain and the salvor of the alleged treasures from the Merchant Royal in June 2007 portray the degree of commercial motivation and national interests in the matter. ${ }^{16}$ In 1986, Christie's was reported to be raising USD 16 million from the sale of 3,786 lots of Chinese porcelain and gold ingots from the famous Nanking Cargo which was salved from the Dutch flagged Geldermahlsen. ${ }^{17}$ However, the auction was soon terminated due to the ensuing controversy, although Christie's claimed to deal with "material recovered legally or under license from historical shipwrecks." ${ }^{18}$ Recovered artefacts from the wreck of the Diana also ended up in auction where the value of all the items recovered, based on transactional prices at the Christie's, was estimated at USD 3.8 million. ${ }^{19}$ This, however, turned into a dispute between the government and the salvor over the alleged distribution of artefacts.

In determining which artefacts get to be retained by the governments, it has been argued that cultural artefacts with "little economic value" but "high cultural value" should be treated differently from those which are of "high economic value" but "low cultural value." 20 This justifies government's ventures with private salvage companies in the exploitation of UCH. Yet, the partnership between commercial salvors and the governments in highly commercial recovery projects has been severely criticized by the archaeological community. ${ }^{21}$ In respect of notorious destruction of the wreck of Geldermahlsen and its site, experts noted that "almost nothing was recorded ... and no proper conservation work was done on the objects raised." 22

In addition, auction houses as well as buyers (such as museums and private collectors who took part in bidding) also face criticism when acquiring coveted cultural objects in auctions. Some curators have been quoted as saying "museums face too

16 M. Z. Mohd Nor, Law and Underwater Cultural Heritage: A Malaysian Perspective (Unpublished Ph.D. Thesis, University of Edinburgh) 96-100 (2009). (on file with Edinburgh Library system).

17 Supra note 15.

18 Id.

19 Malaysia Historical Salvors Sdn Bhd v. Gov. of Malaysia, ICSID Case No. ARB/05/10, Claimant's Supplemental Comments on the Issue of 'Investment,' at 6, available at http://www.italaw.com/sites/default/files/case-documents/ ita0493.pdf (last visited Apr. 15, 2016).

20 P. Fletcher-Tomenius \& C. Forrest, Historic Wrecks in International Waters, 24 MARINE PoL'Y 3 (2001).

21 See, e.g., C. Chaplow, HMS SUSSEX - a PRICELESS english Shipwreck FOUND off Gibraltar, andalucia.com, available at http://www.andalucia.com/history/hmssussex.htm; S. Dromgoole, Murky Waters for Government Policy: The Case of $A 17^{\text {th }}$ Century British Warship and 10 Tonnes of Gold Coins, 28 MARINE PoL'y 189-98 (2004), available at http://www.sciencedirect.com/science/article/pii/S0308597X03001039 (all last visited on May 9, 2016).

22 P. O'Keefe, Shipwrecked Heritage: A Commentary on the UnESCO Convention 8 (2001). 
many awkward decisions when fabulous treasure turns up their doors." ${ }^{23}$ In other words, rather than let these objects into the unknown, they would rather seize the opportunity to acquire, study, and safeguard the items. Museums, some argue, "can't afford to take an all-or-nothing position." ${ }^{24}$

In another perspective, even a pure quest for historical knowledge may not be supported by other interest groups such as family members of a shipwreck tragedy. Disturbance to The Titanic wreck and to the human remains there is certainly an insensitive exploitation of a great tragedy. ${ }^{25}$ Similarly, in the case of sunken warship, the crew remains should be given proper respect as ocean graves. ${ }^{26}$

\section{Reconciling the Prevailing Conflicts}

As seen earlier, the $2001 \mathrm{CPUCH}$ recognizes the multiple interests over UCH. However, this should be translated into a workable solution, avoiding loss in the long run. This section will discuss key aspects of the CPUCH mechanism in ensuring a well-balanced 'mutuality of interest' approach to sustaining UCH for future generation.

\section{A. Multiple Use Approach}

Although commercial exploitation of $\mathrm{UCH}$ is prohibited, ${ }^{27}$ search and recovery of UCH are allowed subject to the principles and objectives of the $2001 \mathrm{CPUCH}^{28}$ which should be properly translated into a workable practice of the Annex Rules to the Convention.

The American Institute of Archaeology advocated the "multiple use management so long as it does not include private sector commercial recovery that is inconsistent

23 H. O'Neill, Treasure Hunts Founder on Laws Shoals, Associated Press, Nov. 29, 1998, available at http://articles. latimes.com/1998/nov/29/news/mn-48720/3 (last visited on May 8, 2016).

24 Id. The article quoted statement made by John Carter of the Philadelphia's Independent Seaport Museum regarding the dilemma faced by Museums.

25 W. Broad, Scientists warn that Visitors are Loving Titanic to Death, N. Y. TimES, Aug. 9, 2003, available at http:// www.nytimes.com/2003/08/09/world/scientists-warn-that-visitors-are-loving-titanic-to-death.html?pagewanted=all (last visited on May 8, 2016).

26 Roach, supra note 4, at 352. See also S. Dromgoole \& N. Gaskell, Who Has a Right to Historic Wrecks and Wreckage?, 17 Int's J. Cultural Prop. 230-1 (1993).

27 The issue of commercial exploitation will be further discussed at Section D below.

28 For a comprehensive treatment on the subject, see supra note 3, at 210-39. 
with basic tenets" as enunciated in the International Council on Monuments and Sites ("ICOMOS") Charter. ${ }^{29}$ The same principle is applied under the 2001 CPUCH. Supporting the economic enjoyment of the UCH, the UNESCO has reported that the excavation of the UCH in Bodrum, Turkey "led to the tripling of the area's population, and it becoming one of the most visited places in Turkey"; the excavation of the Wasa wreck, the most popular tourist site in Stockholm "brings in USD300 per tourist per day to the Swedish economy"; and the Western Australian Maritime Museum attracts some "250,000 visitors per annum (70 percent of visitors coming from outside of the State of Western Australia) bringing an estimated AUD 26.5 million per annum to Western Australia for an annual investment of AUD 1.2 million by the Government of Australia." ${ }^{30}$ By way of comparison, the report noted that although the commercial recovery from the Geldermahlsen wreck raised USD 16 million, "had this China been placed in local museum, this cultural heritage could have raised at least USD 16 million annually in perpetuity for the local community." 31

\section{B. The Public Right of Access to UCH for Enjoyment}

The $2001 \mathrm{CPUCH}$ acknowledges that members of the public have the right to enjoy the heritage. ${ }^{32}$ A layman might ask: how could a cultural property be of any use to anyone, if sunk at the bottom of the ocean, and inaccessible to anyone but a selective few of underwater archaeologists? The government in this respect plays the role in educating the public on the significance of cultural heritage, ${ }^{33}$ giving a proper consideration on in situ access to the heritage for educational purposes. ${ }^{34}$ However, the public right of access to $\mathrm{UCH}$ is not without qualification. Access is generally permissible when it is done non-intrusively without caussing any adverse effect to such heritage. Article 2(10) of the $2001 \mathrm{CPUCH}$ provides that:

29 The Archaeological Institute of America, Comments on the UNESCO / UN Division on Ocean Affairs and the Law of the Sea Draft Convention on the Protection of the Underwater Cultural Heritage, in Background Materials on the Protection of the Underwater Cultural Heritage 176 (L. Prott \& I. Srong eds., 1999), available at hitp://unesdoc. unesco.org/images/0011/001159/115993Mo.pdf (last visited on May 8, 2016).

30 UNESCO, 'Report by the Director General on Action Taken Concerning the Desirability of an International Instrument on the Underwater Cultural Heritage,' UNESCO Doc. 29 C/22, available at http://unesdoc.unesco.org/ images/0010/001089/108953e.pdf (last visited on May 8, 2016).

31 Id.

322001 CPUCH art. 2(10) \& Annex Rule 7.

332001 CPUCH art. 20.

34 Id. Annex Rule 7. 
Responsible non-intrusive access to observe or document in situ underwater cultural heritage shall be encouraged to create public awareness, appreciation, and protection of the heritage except where such access is incompatible with its protection and management. $^{35}$

States should carefully monitor recreational activities such as wreck diving, usually conducting with a commercialized license. ${ }^{36}$ This type of recreational activity may be important for the tourism industry, but problems could arise if monitoring and enforcement of responsible non-intrusive access in these areas are weak.

\section{In situ Preservation}

Managing UCH covers various aspects of 'protection' such as "in situ preservation" and care of $\mathrm{UCH}$ in the period "after its recovery from its underwater environment." $\mathrm{UCH}$ is, like any other archaeological heritage, a 'non-renewable' stock of archaeological and cultural resources. ${ }^{38}$ Compared to ocean's natural resources (flora and fauna), archaeological heritage "cannot reproduce itself, recolonize decimated areas, or be transplanted." 39 Therefore, as a non-renewable resource, it has to be specially guarded against irreparable loss and destruction. ${ }^{40}$ Under the $2001 \mathrm{CPUCH}$, this principle is elaborated in the following terms:

The protection of underwater cultural heritage through in situ preservation shall be considered as the first option. Accordingly, activities directed at underwater cultural heritage shall be authorized in a manner consistent with the protection of that heritage, and subject to that requirement may be authorized for the purpose of making a

35 Id. It provides that: "Public access to in situ underwater cultural heritage shall be promoted, except where such access is incompatible with protection and management."

36 A wreck diver needs to hold a valid diving license, PADI before they can commit themselves to such activities, otherwise committing an offence and any Scuba operator which does not comply with license requirements will face repercussion under relevant laws and wreck diving is even a more specialized activity in Malaysia.

37 G. Carducci, New Developments in the Law of the Sea: The UNESCO Convention on the Protection of the Underwater Cultural Heritage, 96 Aм. J. INT'L L. 426 (2002).

38 H. Cleere, Approaches to the Archaeological Heritage, in New Directions in Archaeology 127 (H. Cleere ed., 1984). See also T. Darvill, Ancient Monuments in the Countryside: An Archaeological Management Review, 5 English Heritage Archaeological Report 1987, available at http://archaeologydataservice.ac.uk/myads/copyrights?from=2f6172 636869766544532f61726368697665446f776e6c6f61643f743d617263682d3134331362d312f64697373656d696e61746 96f6e2f7064662f393738313834383032313332375f414c4c2e 706466 (last visited on 8 May 2016).

39 Darvill, $i d$. at 4.

40 C. McGimsey \& H. Davis (eds.), The Management of Archaeological Resources: The Arlie House Report 9 (1977). See also Cleere, supra note 38; H. Cleere, 1984 Great Britain, in Approaches to the Archaeological Heritage 10 (H. Cleere ed., 2009). 
significant contribution to the protection or knowledge or enhancement of underwater cultural heritage. ${ }^{41}$

In principle, however, "in situ preservation" of UCH is still the preferred method of protection. ${ }^{42}$ Scientific studies on underwater heritage should thus be allowed where researchers can demonstrate the valid benefits of the study to science and its full compliance with the principles of the Convention.

"In situ preservation" should not be seen to be in conflict with the public right to enjoy the cultural heritage for education and recreation. ${ }^{43}$ It should not be interpreted as a kind of absolute prohibition of any form of interference to the heritage and the site they are located in, since interference could be justified if carried out in conformity with the 2001 CPUCH. O'Keefe explained that such an interference is permissible if conducted on the basis of and for 'scientific investigation' in order to safeguard "material from a site threatened by development, natural deterioration, etc." 44

Not surprisingly, the requirement for "in situ preservation" has brought about disagreement from the commercial salvage community who advocated for a more flexible approach for the preservation of $\mathrm{UCH}^{45}$ Such discontent has resulted from the misunderstanding that certain historic wrecks would, unless recovered and conserved, only deteriorate further. ${ }^{46}$ If this view is accepted then "in situ preservation" is not a preferred method of preserving the heritage. The Titanic Guidelines offer guidance into the application of the precautionary principle in protecting UCH. Here, 'in situ preservation' applies the 'precautionary approach.' It is "not intended as a legal presumption against the recovery or salvage of artefacts conducted in a manner consistent with these guidelines," thereby justifying the "recovery or salvage of the artefacts" on the basis of "educational, scientific or cultural interest." 47 An explanatory note on the Titanic Guidelines also purport to erase misunderstanding of the full impact of the notion in situ preservation as

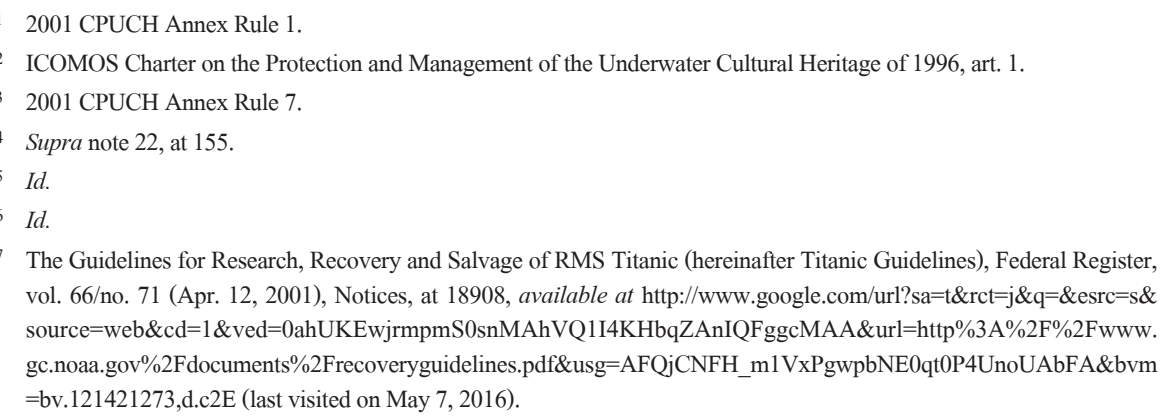
vol. 66/no. 71 (Apr. 12, 2001), Notices, at 18908, available at http://www.google.com/url?sa=t\&rct=j\&q=\&esrc=s\& source=web\&cd=1\&ved=0ahUKEwjrmpmS0snMAhVQ1I4KHbqZAnIQFggcMAA\&url=http $\% 3 \mathrm{~A} \% 2 \mathrm{~F} \% 2 \mathrm{Fwww}$. gc.noaa.gov\%2Fdocuments\%2Frecoveryguidelines.pdf\&usg=AFQjCNFH_m1VxPgwpbNE0qt0P4UnoUAbFA\&bvm $=$ bv.121421273,d.c2E (last visited on May 7, 2016). 
follows:

While the concept of in situ preservation promotes and encourages maintaining the wreckage as it currently exists, it will not prevent recovery or salvage that is determined to be in public interest. Nor does this approach detract from the educational value of the ship or inhibit the public access to the wreck site or to any recovered or salvaged artefacts by the general public. ${ }^{48}$

Thus, those who are against "in situ preservation" of the Titanic argued that "in situ preservation is simply a precautionary management approach and is not intended to create any legal presumption to preclude recovery or salvage" of the wreck. ${ }^{49}$ Instead, great effort must be made for the careful planning and execution of the recovery activities relating to the heritage so that artefacts recovered could be properly preserved, documented and displayed for the benefit of the public. ${ }^{50}$

\section{Prohibition of Commercial Exploitation}

The $2001 \mathrm{CPUCH}$ prohibits commercial exploitation of $\mathrm{UCH}^{51}$ in the form of "trade or speculation or its irretrievable dispersal ... fundamentally incompatible with the protection and proper management of underwater cultural heritage..." and that UCH "shall not be traded, sold, bought or bartered as commercial goods." 52 The final text of this rule was the result of a certain compromise. Thus, "commercial exploitation' would be permitted under the Annex Rules:

a. the provision of professional archaeological services or necessary services incidental thereto whose nature and purpose are in full conformity with this Convention and are subject to the authorization of the competent authorities;

b. the deposition of underwater cultural heritage, recovered in the course of a research project in conformity with this Convention, provided such deposition does not prejudice the scientific or cultural interest or integrity of the recovered material or result in its irretrievable dispersal; is in accordance with the provisions

48 Id. Definition, $\uparrow(\mathrm{d})$.

49 Id.

50 The Guidelines contain extensive rules relating to project design, project timetable, objectives, methodology and techniques, preliminary work assessment, documentation standards, artefacts conservation plan and many other rules relating to the preservation of underwater cultural heritage.

512001 CPUCH art. 2(7).

52 Id. Annex Rule 2. 
of Rules 33 and $34 ;^{53}$ and is subject to the authorization of the competent authorities.

If the rule of prohibition of commercial exploitation is interpreted strictly without considering the qualifications made in the above mentioned rules, all transactions relating to $\mathrm{UCH}$ including the sale and purchase of museum tickets could be regarded as not being in conformity with the objective of the $2001 \mathrm{CPUCH}$. Equating commercialization with 'money making' is counter-productive. Although imposition of entrance fees to museum exhibition of UCH could be interpreted as a money making activity, it is not certainly incompatible with the spirit of the Convention to encourage and create public awareness, and appreciation of such heritage. ${ }^{54}$ In fact, such fees would help cover the costs of running the museums.

'Commissioning' private companies, in the pursuit of search and recovery of significant $\mathrm{UCH}$ if a country lacks both technological expertise and funding, would be a domestic option. ${ }^{55}$ In this case, the government would adopt a balanced approach, maintaining that it is not an act of mere 'commercialization' of such heritage, but an act of 'commissioning' that raises funding for search and recovery. Flecker pointed out in his comments the trend prevalent on shipwreck excavations in Southeast Asia:

Governments cannot afford to excavate shipwrecks and display the recovered artefacts themselves. They generally do not have enough qualified people. A compromise is called for. Commercial companies are necessary to provide finance. Sale of some artefacts is necessary to attract that finance. It is up to the governments to formulate policy that ensures that commercial groups carry out excavation work to acceptable archaeological standards, that they disseminate their results, and that fully representative samples are kept for public display. Governments can certainly benefit financially from the sale of artefacts, but their standing and credibility would be much enhanced if such funds were channelled back into museums and training so that eventually they would be in a position to undertake maritime archaeological projects

53 Rules 33 and 34 deal with the curation of project archives, which is a significant element of the objective of recovery underwater cultural heritage. The Rules provide that: "The project archives, including any underwater cultural heritage removed and a copy of all supporting documentation shall, as far as possible, be kept together and intact as a collection in a manner that is available for professional and public access ... as well as for the curation of the archives. This should be done as rapidly as possible and in any case not later than ten years from the completion of the project, in so far as may be compatible with conservation of the underwater cultural heritage."

$542001 \mathrm{CPUCH}$ art. 2(10)

55 S. Sjostrand, A. Taha \& S. Sahar, Mysteries of Malaysian Shipwrecks 10-23 (2006). 
themselves, independent of commercial companies. ${ }^{56}$

Compared to a similar project along the coastline, underwater search and exploration are about "twenty to fifty times" costlier. ${ }^{57}$ In Malaysia, e.g., the government has been aided by commercial salvors in the search and recovery of significant historic wrecks. This is not always bad news. A well-known commercial company such as the Nanhai Marine Archaeology Sdn Bhd shares recovered artefacts with the National Museum, which maintains these artefacts for conservation, study and display, ${ }^{58}$ while the company, on the other hand, is allowed to sell its allocated shares for financing further work. The company claims to adopt a policy of donating "other artefacts to relevant museums, present the findings from the excavations and research to the widest possible audience, and then to sell the remaining pieces." 59

Such a practice is undertaken by not only developing, but also developed countries. A notable example is the UK's involvement with Odyssey Maritime Explorations, a US based commercial company which discovered the well-known HMS Sussex in Gibraltar. ICOMOS expressed grave concern over this deal days after the adoption of the $2001 \mathrm{CPUCH}$ (where the UK abstained from voting) and called for the parties involved to treat HMS Sussex in line with "best international practice." ${ }^{, 0}$ It alleged that the deal was contrary to the 1996 ICOMOS Charter, which provides that the UCH should not be sold as commercial goods. ${ }^{61}$

Concerning this issue of commercial exploitation of $\mathrm{UCH}$, the commentary on the Titanic Guidelines state that:

Basic professional archaeological standards dictate that artefacts recovered from the wreck site should not be dispersed through the sale of individual artefacts to private collectors such as through auction house sales, [instead], all artefacts from RMS Titanic

56 M. Flecker, The Ethics, Politics and Realities of Maritime Archaeology in Southeast Asia, 31 Int'L J. NaUtical ArchaEology 14-5 (2002).

57 A. Strati, The Protection of the Underwater Cultural Heritage: An Emerging Objective of the Law of the Sea 346 (1995).

58 See Discovering Asia's Ceramic Development, available at http://www.maritimeasia.ws/exhib01/pages/p019.html (last visited on May 7, 2016).

59 Id.

60 See the official website of ICOMOS UK, available at http://www.icomos.org/uk/news/hms_sussex_press.doc (last visited on May 7, 2016).

61 Supra note 42, intro., available at http://www.icomos.org/charters/underwater_e.pdf (last visited on Apr. 18, 2016). It provides: "Commercial exploitation of underwater cultural heritage for trade or speculation is fundamentally incompatible with the protection and management of the heritage." 
should be kept together and intact as project collections. ${ }^{62}$

Following the Guidelines, commercial exploitation does "not necessarily preclude the sale, transfer or trade of an entire collection to a museum or other qualified institution, provided that this commercial transaction does not result in the dispersal of the artefacts. As long as the collection is kept together, maintained for research, education, viewing and other use of public interest." ${ }^{63}$ In other words, there should be no complete ban of commercial transaction in the furtherance of public interest.

\title{
E. Application of Salvage Law
}

The question of application of salvage law or principles is indispensable to the discussion on the search, recovery and exploitation of UCH. Although the 2001 $\mathrm{CPUCH}$ does not exclude the application of salvage law, relevant texts of the Convention were specifically drafted to protect $\mathrm{UCH}$ from the indiscreet application of salvage law principles. Article 4 of the Convention reads:

\begin{abstract}
Any activity relating to underwater cultural heritage to which this convention applies shall not be subject to the law of salvage or law of finds, unless: (a) It is authorized by the competent authorities; (b) It is in full conformity with this Convention; and (c) It ensures that any recovery of the underwater cultural heritage achieves its maximum protection.
\end{abstract}

When a salvage of historic wreck is authorized by a State, the State has the duty to ensure such activities directed at $\mathrm{UCH}$ not to produce more adverse results than what "is necessary for the objectives of the project." ${ }^{64}$ In deciding what is 'necessary', the Annex Rules require:

...non-destructive techniques and survey methods in preference to recovery of objects. If excavation or recovery is necessary for the purpose of scientific studies or for the ultimate protection of the underwater cultural heritage, the methods and techniques used must be as non-destructive as possible and contribute to the preservation of the remain. ${ }^{65}$

62 Titanic Agreement between UK, USA and France, art. 3. See also RMS Titanic Memorial Act 1986.

63 Titanic Guideline, explanatory note, $\mathbf{q \uparrow} 180906$ - 180907.

642001 CPUCH Annex Rule 3.

65 Id. Annex Rule 4. 
Looking back at the drafting history of the $2001 \mathrm{CPUCH}$, the International Law Association attempted to prevent any form of commercialization of such UCH. Although the exclusion of salvage law was later discarded during the negotiation process, some States made an attempt to draft another clause designed to exclude "application of any internal law or regulation having the effect of providing commercial incentives for the excavation and removal of underwater cultural heritage." ${ }^{66}$ Dromgoole argued that had this attempt been successful, it would practically result in salvage laws being totally excluded from the Convention, since the primary object of salvage laws was obviously the commercial incentives for efforts and money spent on salvage. ${ }^{67}$ The attempted exclusion would, needless to say, have been meaningless for any practical purpose.

As mentioned earlier, in Malaysia, all recovery projects involving historic wrecks have so far been undertaken by the commercial salvage company, which has necessary technology and expertise in deep underwater recovery. Without such partnership, certain significant historic shipwrecks such as the Diana would remain on the ocean floor unknown and unstudied. Although many of the artefacts recovered from the wreck of the Diana were disposed in an Amsterdam auction house in 1992, it also resulted in a proper documentation relating to the wreck with significant artefacts retained by the Malaysian government. The government also purchased many of these artefacts during that auction. ${ }^{68}$ Indonesia and the UK took a similar approach in the salvage of the Geldermahlsen ${ }^{69}$ and the HMS Suusex, respectively. ${ }^{70}$

\section{Conclusion}

Any laws designed to protect UCH must give due consideration to these competing interests ranging from public to private, commercial and non-commercial in nature.

661998 Draft CPUCH art. 12(2), available at http://unesdoc.unesco.org/images/0011/001159/115994eo.pdf (last visited on May 7, 2016)

67 S. Dromgoole, 2001 UNESCO Convention on the Protection of the Underwater Cultural Heritage, 18 INT'L J. MARINE \& CoAstal L. 70 (2003).

68 Artefacts from the Diana wreck are displayed in maritime archaeology museum in Kuala Lumpur which was established in late 2001 as a temporary museum. For details on wrecks exhibited at the museum, see supra note 56, at $8-10 . s$

69 G. Miller, The Second Destruction of the Geldermalsen, 26 Historical ArchaEology 124-31 (1992).

70 See discussion in Section 3(D). 
Commercially related interests of the salvage industry and other recreational tourism sectors such as scuba and wreck diving activities must be given proper consideration as legitimate interests under the $2001 \mathrm{CPUCH}$ by adhering to the established archaeological principles provided under the Convention. In order to ensure sustainability of UCH, "in situ preservation" should be applied as a first rule, but not as a bar to other legitimate interests whether commercial or non-commercial. In addition, where recovery and salvage become necessary and viable, they must be authorised under the law and adhere to the principles and rules of the $2001 \mathrm{CPUCH}$. Recognizing the mutual interests over $\mathrm{UCH}$ and respecting the principles and rules as established under the Convention would achieve the most desired outcome, i.e., balance of the competing interests. 
